\title{
Piroxantrone Hydrochloride
}

National Cancer Institute

\section{Source}

National Cancer Institute. Piroxantrone Hydrochloride. NCI Thesaurus. Code C72829.

The hydrochloride salt form of piroxantrone, an anthrapyrazole antineoplastic antibiotic.

Piroxantrone intercalates into DNA and interacts with topoisomerase II, thereby inhibiting DNA replication and repair as well as RNA and protein synthesis. Although less cardiotoxic than doxorubicin, this agent exhibits a narrow spectrum of antineoplastic activity. 